\title{
Nutritional Analysis and Quality Evaluation in Muscle of Crucifix Crab Charybdis feriatus From Three Wild Populations
}

\author{
Jian-xue Lu ${ }^{1}$, Yang-yang Gong ${ }^{1}$, Yan-qing Huang ${ }^{1}$, Hong-yu Ma ${ }^{1}$, Xiong Zou ${ }^{1}$ \& Lian-jun Xia ${ }^{1}$ \\ ${ }^{1}$ Key Laboratory of East China Sea \& Oceanic Fishery Resources Exploitation and Utilization, Ministry of \\ Agriculture, East China Sea Fisheries Research Institute, Chinese Academy of Fishery Sciences, Shanghai, \\ China \\ Correspondence: Lian-jun Xia, Key Laboratory of East China Sea \& Oceanic Fishery Resources Exploitation \\ and Utilization, East China Sea Fisheries Research Institute, Chinese Academy of Fishery Sciences, Shanghai \\ 200090, China. Tel: 86-021-65680318. E-mail: taurusapr@126.com
}

Received: December 16, 2013 Accepted: January 8, 2014 Online Published: January 13, 2014

doi:10.5539/jfr.v3n2p27 URL: http://dx.doi.org/10.5539/jfr.v3n2p27

\begin{abstract}
Three wild populations of crucifix crab Charybdis feriatus were sampled and muscle was analyzed for proximate composition, amino acid and fatty acid composition, aimed to quantify and compare the nutritional quality from three different locations in China. Results showed that crude protein content in muscle of female crucifix crab $C$. feriatus from Zhoushan (ZS) and Xiapu (XP) (84.84\%-88.35\%) were significantly higher than that of crucifix crab C. feriatus from Qionghai $(\mathrm{QH})(74.33 \%)$, while there was no significant difference in terms of crude fat content (3.82\%-4.07\%). The highest content of ash was found in muscle of crucifix crab C. feriatus from $\mathrm{QH}$ $(5.36 \%)$. The muscle of crucifix crab C. feriatus from ZS and XP had significantly higher contents of total amino acids, essential amino acids, non-essential amino acids and delicious amino acids than those of QH group $(P<$ 0.05). The total saturated and unsaturated fatty acid content in the muscle of crucifix crab $C$. feriatus from three wild populations showed significant difference $(P<0.05)$. The ZS group had highest content of poly-unsaturated fatty acids (33.64\%) and total content of EPA and DHA $(22.85 \%)$ as well, followed by XP and QH group $(P<$ $0.05)$. Overall, the differences in chemical composition in muscle of $C$. feriatus from different locations could be attributed to environmental variables and maturation stage.
\end{abstract}

Keywords: Charybdis feriatus, wild population, proximate composition, amino acid, fatty acid

\section{Introduction}

Crustaceans are beneficial and highly appreciated due to their favorable taste and nutritional quality. In the last decades, the chemical composition and nutritional value of crustaceans have been investigated intensively (Skonberg \& Perkins, 2002; Çelik et al., 2004; Naczk et al., 2004; Küçükgülmez et al., 2006; Chen et al., 2007; Barrento et al., 2009a; Barrento et al., 2009b; Barrento et al., 2010; Marques et al., 2010; Tsape et al., 2010; Wu et al., 2010; Maulvault et al., 2012; Risso \& Carelli, 2012). The taste and nutritional quality of crab meat is to a large extent related to the presence of amino acids and fatty acids (Chen et al., 2007). And a balanced amino acid and fatty acid composition is essential for promoting good health as well (Wu et al., 2010).

The crucifix crab, Charybdis feriatus, is one of the most consumed crustaceans in countries of East and Southeast Asia (Josileen, 2011). The meat of this crab is particularly tasty and desirable, and is available throughout the whole year. This crab has a striking feature of distinctive red, black and white exoskeleton with a cross on the median surface of the carapace (Padayatti, 1990). The juvenile crucifix crab selects its habitat in the sandy shore, and the adult inhabits muddy offshore areas (Baylon \& Suzuki, 2007). This crab is abundantly distributed in the eastern and southeastern coasts of mainland China and is mostly captured and consumed in coastal areas of Zhejiang, Fujian and Hainan provinces. Considering that the chemical composition of a particular species may vary according to habitat (Souchet \& Laplante, 2007; Barrento et al., 2010), the aim of this study was to determine nutritional composition and quality of the muscle of crucifix crab Charybdis feriatus captured from these three geographical locations in China. In particular, proximate chemical composition, amino acid content and fatty acid composition among the populations were investigated and compared. To the best of our knowledge, this is the first study to report the chemical composition of crucifix crab, and the results would give additional nutritional information to consumers. 


\section{Materials and Methods}

\subsection{Sampling}

A total of 45 female crucifix crabs of species Charybdis feriatus were captured from 3 different locations along the southeastern coastal waters of China in March, 2013, including Zhoushan (ZS), Zhejiang province (305.09 \pm $23.66 \mathrm{~g}, \mathrm{n}=15)$, Xiapu (XP), Fujian province $(306.71 \pm 37.24 \mathrm{~g}, \mathrm{n}=15)$ and Qionghai (QH), Hainan province $(307.99 \pm 32.52 \mathrm{~g}, \mathrm{n}=15)$. These locations are listed in Table 1. Wild adult specimens collected from these locations were transported to laboratory immediately, weighed and prepared for sampling the muscle. Each set of 15 crabs was divided into three groups and muscle (including claws, walking legs and body) from each group (5 specimens) were pooled together. Each sample was subsequently homogenized with a grinder, packed in small plastic bags and stored at $-40{ }^{\circ} \mathrm{C}$ until analysis.

Table 1. Characteristics of three locations of Charybdis feriatus

\begin{tabular}{lllll}
\hline Location & Code & Capacity & Latitude (N) & Longitude (E) \\
\hline Zhoushan & ZS & 15 & $29^{\circ} 16^{\prime \prime}$ & $122^{\circ} 08^{\prime \prime}$ \\
Xiapu & XP & 15 & $26^{\circ} 46^{\prime \prime}$ & $120^{\circ} 42^{\prime \prime}$ \\
Qionghai & QH & 15 & $19^{\circ} 36^{\prime \prime}$ & $110^{\circ} 13^{\prime \prime}$ \\
\hline
\end{tabular}

\subsection{Proximate Composition Analysis}

The crab muscle samples were analyzed for moisture, protein, lipid and ash by using AOAC 2005 (Association of Official Analytical Chemists) standard methods 950.46, 928.08, 991.36 and 920.153, respectively. In brief, moisture was determined by drying the samples at $105^{\circ} \mathrm{C}$ to constant weight. Crude protein was measured by determining nitrogen content $(\times 6.25)$ using automated Kjeldahl analysis (Foss Tecator Kjeltec Auto 2200 analyzer, Warrington, UK). Lipid was determined by petroleum ether extraction in a soxlet apparatus (Foss Tecator 148 Soxtec system 2043 Auto Extraction apparatus, Warrington, UK). Ash was determined by combustion to a constant weight in a muffle furnace at $550{ }^{\circ} \mathrm{C}$ (Lindberg/Blue M, Thermo Fisher Scientific Inc., Waltham, USA).

\subsection{Amino Acid Composition Analysis}

For amino acid analysis, the samples were hydrolyzed with $6 \mathrm{~mol} \cdot \mathrm{L}^{-1} \mathrm{HCL}$ and determined by amino acids analyzer (Biochrom Ltd., Cambridge, UK) with a C18 column $(25 \mathrm{~cm} \times 4.6 \mathrm{~mm})$, according to the method of Chinese Standard GB/T 5009.124-2003. For measuring tryptophan content, each sample was hydrolyzed with 5 $\mathrm{mol} \cdot \mathrm{L}^{-1} \mathrm{NaOH}$ before analysis. The amino acid content was calculated by comparison with retention time and the peak areas of standard amino acids.

\subsection{Fatty Acid Composition Analysis}

For fatty acid analysis, total lipids of samples were extracted and fatty acid methyl esters were prepared in accordance with Chinese Standard GB/T 22223-2008. Briefly, total lipids were extracted with chloroform-methanol solution (2:1, v/v). Fatty acid methyl esters (FAMEs) were prepared using a $15 \%(\mathrm{w} / \mathrm{v})$ BF3-methanol reagent. FAMEs were measured by using HP-6890 GC series gas chromatograph and a column $(60 \mathrm{~m} \times 0.25 \mathrm{~mm} \times 0.25 \mu \mathrm{m})$. Nitrogen was the gas carrier and the column temperature was set to increase from $130{ }^{\circ} \mathrm{C}$ to $230{ }^{\circ} \mathrm{C}$, at a rate of $4{ }^{\circ} \mathrm{C} / \mathrm{min}$. The fatty acids composition was determined by comparing the areas of the various fatty acids analyzed to the areas of a fixed concentration of the individual and mixed FAME standard.

\subsection{Calculations and Statistical Analysis}

Amino acid score (AAS) was calculated according to FAO/WHO reference amino acid standard for adults, and the chemical score (CS) was calculated with respect to the amino acid composition of egg protein. The AAS and CS were calculated using the following formula (Biel et al., 2009; Gong et al., 2013):

Amino acid score $=$ Sample amino acid $(\mathrm{mg} / \mathrm{g} \mathrm{N}) / \mathrm{FAO} / \mathrm{WHO}$ reference amino acid $(\mathrm{mg} / \mathrm{g} \mathrm{N})$

Chemical score $=$ Sample amino acid $(\mathrm{mg} / \mathrm{g} \mathrm{N}) /$ amino acid of egg protein $(\mathrm{mg} / \mathrm{g} \mathrm{N})$.

The propensity of crab muscle to the incidence of coronary heart disease, atherogenic index (AI) and thrombogenic index (TI) were calculated according to the following formula (Barrento et al., 2010):

$\mathrm{AI}$, atherogenic index $=(\mathrm{C} 12: 0+4 \times \mathrm{C} 14: 0+\mathrm{C} 16: 0) /[(\mathrm{MUFA}+\mathrm{PUFA}(\mathrm{n}-6)$ and $(\mathrm{n}-3)]$ 
TI, thrombogenic index $=(\mathrm{C} 14: 0+\mathrm{C} 16: 0+\mathrm{C} 18: 0) /[(0.5 \times$ PUFA $+0.5 \times$ PUFA $(\mathrm{n}-6)+3 \times$ PUFA $(\mathrm{n}-3)+(\mathrm{n}-3) /$ $(\mathrm{n}-6)]$.

Analyses were carried out in triplicate and the results were presented as mean and standard deviation (means \pm SD). The data were analyzed by one-way analysis of variance (ANOVA) through SAS 9.0 statistical software (SAS Institute Inc., Cary, NC, USA). Significant $(P<0.05)$ differences among the samples were ranked by Duncan's Multiple Range Test.

\section{Results and Discussion}

\subsection{Proximate Chemical Composition}

Proximate chemical composition of crab muscle samples from three wild populations is shown in Table 2. The crab muscle had an average moisture content of $78.93 \%$, in which $\mathrm{QH}$ group showed highest contribution (80.26\%), followed by ZS group (78.70\%) and XP group (77.83\%). Crude protein content of muscle averaged between $74.33 \%-88.35 \%$ and together with lower content of crude lipid (3.82\%-4.07\%) in dry weight basis. These results were similar to those of other reported crab species, which were determined to be $80.60 \%-88.97 \%$, $2.00 \%-4.25 \%$ of crude protein and crude lipid in dry weight, respectively (Skonberg \& Perkins, 2002; Küçükgülmez et al., 2006; Chen et al., 2007; Maulvault et al., 2012). Differences in proximate composition were observed among the sampled populations from three fishing locations. QH population had the lowest protein content $(74.33 \%)$, compared with those from the other two populations $(P<0.05)$. No significant differences in lipid content were observed among three populations $(P<0.05)$. The highest ash content was found in $\mathrm{QH}$ population $(5.36 \%)$, followed by XP (4.41\%) and ZS population (4.23\%). The similar proximate composition found in ZS and XP group might be much closer geographic habitats with similar living environments.

Table 2. Proximate chemical composition of three wild populations of Charybdis feriatus (\%, dry weight) $\mathrm{n}=3$, means $\pm \mathrm{SD}$

\begin{tabular}{llll}
\hline Nutritional components & ZS & XP & QH \\
\hline Moisture & $78.70 \pm 0.97$ & $77.83 \pm 0.60$ & $80.26 \pm 1.21$ \\
In dry weight, \% & & & \\
Crude protein & $84.83 \pm 0.65^{\mathrm{a}}$ & $88.35 \pm 1.23^{\mathrm{a}}$ & $74.33 \pm 1.55^{\mathrm{b}}$ \\
Crude fat & $3.94 \pm 0.01^{\mathrm{a}}$ & $3.82 \pm 0.02^{\mathrm{a}}$ & $4.07 \pm 0.02^{\mathrm{a}}$ \\
Ash & $4.23 \pm 0.02^{\mathrm{c}}$ & $4.41 \pm 0.02^{\mathrm{b}}$ & $5.36 \pm 0.30^{\mathrm{a}}$ \\
\hline
\end{tabular}

ZS, crabs from Zhoushan; XP, crabs from Xiapu; QH, crabs from Qionghai

Within the same row, values with different superscripts are significantly different $(P<0.05)$.

\subsection{Amino Acid Composition}

The detailed amino acid composition of muscle sampled from three wild populations is given in Table 3 . The most abundant amino acid in the samples was glutamic acid (11.05\%-12.42\%), followed by aspartic acid (6.86\%-7.61\%), arginine (6.58\%-7.46\%), lysine (5.71\%-6.41\%), glycine (5.51\%-5.86\%), leucine (5.27\%-5.79\%), and alanine (3.45\%-4.41\%) in decreasing amount. The lowest content of amino acid was tryptophan among the three wild populations. High levels of taurine were found in muscle samples which are between $0.80 \%$ and $1.23 \%$. Taurine is not incorporated in protein synthesis, but it plays a vital role in physiological functions during development and aging (Ripps \& Shen, 2012). Since humans have limitation in biosynthesizing of taurine, the dietary supplementation seems to be necessary. No significant difference in any single amino acid content was found among the samples in the present study. The total amino acid (TAA) content ranged from $70.22 \%$ to $78.55 \%$. The essential amino acids (EAA) content of all samples $(23.56 \%-26.57 \%)$ was found to be lower than non-essential amino acids (NEAA) content (46.67\%-51.98\%), and the ratio of EAA/NEAA ranged from 57.37\% to $58.16 \%$. The amino acid pattern of higher amounts of non-essential amino acids was found in other reported crustaceans as well (Barrento et al., 2010; Wu et al., 2010). The EAA and delicious amino acids (DAA) accounted for $33.54 \%-33.82 \%$, and $38.12 \%-38.42 \%$ of total amino acid content (TAA) of the muscle samples, respectively. Variations among different locations were also observed in amino acid content. Among three wild populations, significant higher content of EAA, NEAA, DAA and TAA was found in ZS and XP group than QH group $(P<0.05)$ as found in protein content. In general, muscle is the main protein storage location in crabs. 
Environmental factors (water temperature, salinity, dissolved oxygen, photoperiod, and diet type and availability) and maturation stage would have effect on protein metabolism in crab muscles, resulting in different amino acid contents of crabs at different locations (Antunes et al., 2010).

Table 3. Amino acid content of three wild populations of Charybdis feriatus ( $\%$, dry weight $) \mathrm{n}=3$, means $\pm \mathrm{SD}$

\begin{tabular}{|c|c|c|c|}
\hline Amino acids & ZS & $\mathrm{XP}$ & $\mathrm{QH}$ \\
\hline Taurine & $1.23 \pm 0.01$ & $1.01 \pm 0.01$ & $0.80 \pm 0.01$ \\
\hline Aspartic acid & $7.61 \pm 0.09$ & $7.29 \pm 0.12$ & $6.86 \pm 0.06$ \\
\hline Threonine & $3.31 \pm 0.05$ & $3.27 \pm 0.03$ & $3.09 \pm 0.03$ \\
\hline Serine & $3.07 \pm 0.04$ & $3.00 \pm 0.05$ & $2.88 \pm 0.01$ \\
\hline Glutamic acid & $12.42 \pm 0.14$ & $12.40 \pm 0.17$ & $11.05 \pm 0.10$ \\
\hline Glycine & $5.51 \pm 0.06$ & $5.86 \pm 0.08$ & $5.54 \pm 0.05$ \\
\hline Alanine & $4.41 \pm 0.03$ & $4.15 \pm 0.12$ & $3.45 \pm .74$ \\
\hline Valine & $3.31 \pm 0.01$ & $3.21 \pm 0.05$ & $2.98 \pm 0.03$ \\
\hline Methionine & $1.50 \pm 0.03$ & $1.58 \pm 0.03$ & $0.93 \pm 0.01$ \\
\hline Isoleucine & $3.09 \pm 0.04$ & $3.06 \pm 0.03$ & $2.78 \pm 0.03$ \\
\hline Leucine & $5.79 \pm 0.10$ & $5.71 \pm 0.08$ & $5.27 \pm 0.05$ \\
\hline Tyrosine & $3.05 \pm 0.02$ & $2.91 \pm 0.04$ & $2.64 \pm 0.02$ \\
\hline Phenylalanine & $3.15 \pm 0.03$ & $3.06 \pm 0.06$ & $2.80 \pm 0.03$ \\
\hline Histidine & $2.06 \pm 0.01$ & $1.87 \pm 0.05$ & $1.82 \pm 0.02$ \\
\hline Lysine & $6.41 \pm 0.07$ & $6.23 \pm 0.07$ & $5.71 \pm 0.05$ \\
\hline Arginine & $7.31 \pm 0.08$ & $7.46 \pm 0.11$ & $6.58 \pm 0.06$ \\
\hline Proline & $2.92 \pm 0.03$ & $2.82 \pm 0.07$ & $2.69 \pm 0.03$ \\
\hline Cystine & $3.02 \pm 0.07$ & $2.79 \pm 0.07$ & $2.64 \pm 0.02$ \\
\hline Tryptophan & $0.62 \pm 0.00$ & $0.63 \pm 0.00$ & $0.52 \pm 0.00$ \\
\hline TAA & $78.55 \pm 0.91^{\mathrm{a}}$ & $77.29 \pm 1.25^{\mathrm{a}}$ & $70.22 \pm 1.34^{\mathrm{b}}$ \\
\hline EAA & $26.57 \pm 0.33^{\mathrm{a}}$ & $26.12 \pm 0.35^{\mathrm{a}}$ & $23.56 \pm 0.22^{\mathrm{b}}$ \\
\hline NEAA & $51.98 \pm 0.58^{\mathrm{a}}$ & $51.17 \pm 0.90^{\mathrm{a}}$ & $46.67 \pm 1.13^{\mathrm{b}}$ \\
\hline DAA & $29.94 \pm 0.31^{\mathrm{a}}$ & $29.70 \pm 0.49^{\mathrm{a}}$ & $26.90 \pm 0.96^{\mathrm{b}}$ \\
\hline EAA/TAA & 33.82 & 33.79 & 33.54 \\
\hline EAA/NEAA & 58.05 & 58.16 & 57.37 \\
\hline DAA/TAA & 38.12 & 38.42 & 38.30 \\
\hline
\end{tabular}

ZS, crabs from Zhoushan; XP, crabs from Xiapu; QH, crabs from Qionghai.

Within the same row, values with different superscripts are significantly different $(P<0.05)$.

As shown in Table 4, the amino acid score (AAS) in three sampled populations was with no difference, and the scores were similar or higher than reference FAO/WHO pattern except for valine and tryptophan (AAS $<0.8$ ), while the chemical score (CS) of amino acid was lower than the reference egg protein data except for lysine (CS > 1.0). The high lysine content in crab muscle samples could be a supplementation of plant-protein based diets. Tryptophan was found to be the EAA with the lowest content, and it would be the limiting amino acid in muscle of crucifix crab Charybdis feriatus. 
Table 4. AAS and CS among three wild populations of Charybdis feriatus

\begin{tabular}{lllllll}
\hline & Amino acids & $\begin{array}{l}\text { FAO/WHO } \\
\text { pattern }\end{array}$ & Egg protein & ZS & XP & QH \\
\hline \multirow{4}{*}{ Ile } & 250 & & 0.91 & 0.87 & 0.94 \\
& Leu & 440 & & 0.97 & 0.92 & 1.01 \\
& Lys & 340 & & 1.39 & 1.30 & 1.41 \\
AAS & Met+Cys & 220 & & 1.51 & 1.40 & 1.36 \\
& Phe+Tyr & 380 & & 1.20 & 1.11 & 1.20 \\
& Thr & 250 & & 0.98 & 0.93 & 1.04 \\
& Val & 310 & & 0.79 & 0.74 & 0.81 \\
& Trp & 60 & 331 & 0.76 & 0.73 & 0.73 \\
& Ile & & 0.69 & 0.65 & 0.71 \\
& Leu & & 0.80 & 0.76 & 0.83 \\
& Lys & & 1.07 & 1.01 & 1.09 \\
Met+Cys & & 386 & 0.86 & 0.80 & 0.78 \\
CS & & 565 & 0.81 & 0.75 & 0.81 \\
& Phe+Tyr & & 0.84 & 0.79 & 0.89 \\
Thr & & 411 & 0.59 & 0.55 & 0.61 \\
Val & & 106 & 0.43 & 0.42 & 0.41 \\
\hline Trp & & & &
\end{tabular}

AAS, amino acid score; CS, chemical score.

\subsection{Fatty Acid Composition}

The fatty acid composition of muscle sampled from three wild populations is given in Table 5. The saturated fatty acids (SFA) $(37.73 \%-42.55 \%$ of total lipid) were found to be the main group of fatty acids in three samples followed by polyunsaturated fatty acids (PUFA) (25.87\%-33.64\% of total lipid) and monounsaturated fatty acids (MUFA) (28.49\%-32.84\% of total lipid). Variations among wild populations were also found in crab's FA profile. For instance, QH population had the highest SFA compared with that of the other two populations $(P<$ $0.05)$. Content of PUFA in muscle samples were in descending order: ZS $(33.64 \%)>\mathrm{XP}(29.44 \%)>\mathrm{QH}$ (25.87\%). The most abundant saturated fatty acid in samples was palmitic acid (C16:0), similar to the data obtained from reports of other crab species (Barrento et al., 2010; Maulvault et al., 2012). For monounsaturated fatty acids, the oleic acid (C18:1n-9) was the most abundant fatty acid. Docosahexaenoic acid (DHA, 22:6n-3) and eicopentaenoic acid (EPA, 20:5n-3) were the main PUFA in muscle samples. Similarly high amount of DHA and EPA is also reported in other crab species in literatures (Barrento et al., 2010; Marques et al., 2010; Maulvault et al., 2012). These two fatty acids are related to lower risk of cardiovascular disease and inflammation (Breslow, 2006; Calder, 2006). The total amount of EPA and DHA were considerably higher in ZS group than that of the other two wild groups $(P<0.05)$. The n-3 and n-6 PUFA of the samples ranged $24.72 \%-32.04 \%$ and $1.15 \%-1.71 \%$ of the total lipid, respectively. And the higher percentage of total n-3 PUFA $(P<0.05)$ in ZS group were mainly due to higher amount of DHA and EPA. The ratio of n-3 to n-6 PUFA in the present study ranged from 16.27 to 21.46 , which is higher than those reported marine crabs (2.55-5.24) (Barrento et al., 2010; Wu et al., 2010; Maulvault et al., 2012). The AI and TI in the samples was 0.38-0.43 and 0.28-0.35, respectively. The values in this crab muscle were lower when compared to those of land animals $(0.50-1.00)$ (Rosa \& Nunes, 2004), indicating lower incidence of coronary heart disease. The differences in crab's fatty acid profile is considered to be environmental variables (e.g. water temperature, salinity, diet type and availability) and different stage of maturation of crabs captured from different locations as well (Vinagre et al., 2007; Antunes et al., 2010). 
Table 5. Fatty acid composition among three wild populations of Charybdis feriatus (\% of total lipid) $\mathrm{n}=3$, means $\pm \mathrm{SD}$

\begin{tabular}{lccc}
\hline Fatty acids & ZS & XP & QH \\
\hline C15:0 & $0.88 \pm 0.06$ & $0.67 \pm 0.33$ & $1.29 \pm 0.14$ \\
C16:0 & $24.73 \pm 0.01$ & $23.48 \pm 0.37$ & $24.49 \pm 0.51$ \\
C17:0 & $0.45 \pm 0.07$ & $0.63 \pm 0.22$ & $2.15 \pm 0.71$ \\
C18:0 & $11.80 \pm 0.27$ & $12.94 \pm 0.11$ & $14.62 \pm 0.87$ \\
C16:1 & $6.09 \pm 0.07$ & $7.75 \pm 0.01$ & $3.08 \pm 0.76$ \\
C18:1n9 & $22.11 \pm 0.18$ & $24.72 \pm 0.06$ & $28.30 \pm 0.67$ \\
C20:1n9 & $0.29 \pm 0.08$ & $0.37 \pm 0.14$ & - \\
C18:2n6 & $1.24 \pm 0.14$ & $1.39 \pm 0.26$ & $1.15 \pm 0.54$ \\
C20:2n6 & $0.36 \pm 0.51$ & $0.32 \pm 0.05$ & - \\
C20:3n3 & $9.19 \pm 0.06$ & $7.52 \pm 0.18$ & $9.22 \pm 0.28$ \\
C20:5n3(EPA) & $12.69 \pm 0.32$ & $11.96 \pm 0.33$ & $9.59 \pm 0.38$ \\
C22:5n3 & - & $0.85 \pm 0.17$ & - \\
C22:6n3(DHA) & $10.16 \pm 0.34$ & $7.40 \pm 0.03$ & $5.92 \pm 0.07$ \\
SFA & $37.87 \pm 0.25^{\mathrm{b}}$ & $37.73 \pm 0.15^{\mathrm{b}}$ & $42.55 \pm 1.22^{\mathrm{a}}$ \\
MUFA & $28.49 \pm 0.02^{\mathrm{b}}$ & $32.84 \pm 0.08^{\mathrm{a}}$ & $31.58 \pm 0.09^{\mathrm{a}}$ \\
PUFA & $33.64 \pm 0.23^{\mathrm{a}}$ & $29.44 \pm 0.23^{\mathrm{b}}$ & $25.87 \pm 1.12^{\mathrm{c}}$ \\
n-6 & $1.60 \pm 0.38$ & $1.71 \pm 0.19$ & $1.15 \pm 0.54$ \\
n-3 & $32.04 \pm 0.60^{\mathrm{a}}$ & $27.73 \pm 0.05^{\mathrm{b}}$ & $24.72 \pm 0.58^{\mathrm{c}}$ \\
EPA+DHA & $22.85 \pm 0.66^{\mathrm{a}}$ & $19.36 \pm 0.30^{\mathrm{b}}$ & $15.50 \pm 0.30^{\mathrm{c}}$ \\
n-3/n-6 & 20.01 & 16.27 & 21.46 \\
AI & 0.40 & 0.38 & 0.43 \\
TI & 0.28 & 0.31 & 0.35 \\
\hline
\end{tabular}

ZS, crabs from Zhoushan; XP, crabs from Xiapu; QH, crabs from Qionghai; AI, atherogenic index; TI, thrombogenic index.

Within the same row, values with different superscripts are significantly different $(P<0.05)$.

\section{Conclusions}

The present study was carried out to quantify the chemical composition and nutritional value of crucifix crab Charybdis feriatus captured from three geographical locations in China. This is, to the best of our knowledge, the first study documenting the amino acid content, fatty acid composition of crucifix crab C. feriatus. Crabs are exposed to environmental variables in different habitats, such as water temperature, salinity, dissolved oxygen, photoperiod, and diet type and availability or maturation stage-all of which may produce differences in chemical composition.

\section{Acknowledgements}

This work was supported by a special research fund (Project NO. 2012M04) for the national non-profit institutes (East China Sea Fisheries Research Institute).

\section{References}

Antunes, G. D. F., do Amaral, A. P. N., Ribarcki, F. P., Wiilland, E. D. F., Zancan, D. M., \& Vinagre, A. S. (2010). Seasonal variations in the biochemical composition and reproductive cycle of the ghost crab Ocypode quadrata (Fabricius, 1787) in Southern Brazil. Journal of Experimental Zoology Part A: Ecological Genetics and Physiology, 313A, 280-291. http://dx.doi.org/10.1002/jez.593

AOAC. (2005). Official methods of analysis (18th ed.). Association of Official Analytical Chemists, Washington 


\section{D.C. USA}

Barrento, S., Marques, A. N., Teixeira, B. R., Anacleto, P. C., Vaz-Pires, P., \& Nunes, M. L. (2009a). Effect of Season on the Chemical Composition and Nutritional Quality of the Edible Crab Cancer pagurus. Journal of Agricultural and Food Chemistry, 57, 10814-10824. http://dx.doi.org/10.1021/jf9025597

Barrento, S., Marques, A. N., Teixeira, B. R., Vaz-Pires, P., \& Nunes, M. L. (2009b). Nutritional Quality of the Edible Tissues of European Lobster Homarus gammarus and American Lobster Homarus americanus. Journal of Agricultural and Food Chemistry, 57, 3645-3652. http://dx.doi.org/10.1021/jf900237g

Barrento, S., Marques, A., Teixeira, B., Mendes, R., Bandarra, N., Vaz-Pires, P., \& Nunes, M. L. (2010). Chemical composition, cholesterol, fatty acid and amino acid in two populations of brown crab Cancer pagurus: Ecological and human health implications. Journal of Food Composition and Analysis, 23, 716-725. http://dx.doi.org/10.1016/j.jfca.2010.03.019

Baylon, J., \& Suzuki, H. (2007). Effects of changes in salinity and temperature on survival and development of larvae and juveniles of the crucifix crab Charybdis feriatus. Aquaculture, 269, 390-401. http://dx.doi.org/10.1016/j.aquaculture.2007.03.024

Biel, W., Bobko, K., \& Maciorowski, R. (2009). Chemical composition and nutritive value of husked and naked oats grain. Journal of Cereal Science, 49, 413-418. http://dx.doi.org/10.1016/j.jcs.2009.01.009

Breslow, J. L. (2006). n-3 Fatty acids and cardiovascular disease. The American Journal of Clinical Nutrition, 83, 1477-1482. Retrieved from http://ajcn.nutrition.org/content/83/6/S1477.full

Calder, P. C. (2006). n-3 Polyunsaturated fatty acids, inflammation, and inflammatory diseases. The American Journal of Clinical Nutrition, 83, 1505-1519. $\quad$ Retrieved from http://ajcn.nutrition.org/content/83/6/S1505.full

Chen, D. W., Zhang, M., \& Shrestha, S. (2007). Compositional characteristics and nutritional quality of Chinese mitten crab (Eriocheir sinensis). Food Chemistry, 103, 1343-1349. http://dx.doi.org/10.1016/j.foodchem.2006.10.047

Çelik, M., Türeli, C., Çelik, M., Yanar, Y., Erdem, Ü., \& Küçükgülmez, A. (2004). Fatty acid composition of the blue crab (Callinectes sapidus Rathbun, 1896) in the north eastern Mediterranean. Food Chemistry, 88, 271-273. http://dx.doi.org/10.1016/j.foodchem.2004.01.038

Dutra, B. K., Santos, R. B., Bueno, A. A. P., \& Oliveira, G. T. (2008). Seasonal variations in the biochemical composition and lipoperoxidation of Hyalella curvispina (Crustacea, Amphipoda). Comparative Biochemistry and Physiology Part A: Molecular \& Integrative Physiology, 151, 322-328. http://dx.doi.org/10.1016/j.cbpa.2007.01.725

Gong, Y., Huang, Y., Gao, L., Lu, J., Hu, Y., Xia, L., \& Huang, H. (2013). Nutritional Composition of Caviar from Three Commercially Farmed Sturgeon Species in China. Journal of Food and Nutrition Research, 1, 108-112. http://dx.doi.org/10.12691/jfnr-1-5-5

Josileen, J. (2011). Captive spawning, hatching and larval development of crucifix crab, Charybdis feriatus (Linnaeus, 1758). Journal of Marine Biological Association of India, 53, 35-40.

Küçükgülmez, A., Çelik, M., Yanar, Y., Ersoy, B., \& Çikrikçi, M. (2006). Proximate composition and mineral contents of the blue crab (Callinectes sapidus) breast meat, claw meat and hepatopancreas. International Journal of Food Science \& Technology, 41, 1023-1026. http://dx.doi.org/10.1111/j.1365-2621.2006.01159.x

Marques, A., Teixeira, B., Barrento, S., Anacleto, P., Carvalho, M. L., \& Nunes, M. L. (2010). Chemical composition of Atlantic spider crab Maja brachydactyla: Human health implications. Journal of Food Composition and Analysis, 23, 230-237. http://dx.doi.org/10.1016/j.jfca.2009.10.007

Maulvault, A. L., Anacleto, P., Lourenço, H. M., Carvalho, M. L., Nunes, M. L., \& Marques, A. (2012). Nutritional quality and safety of cooked edible crab (Cancer pagurus). Food Chemistry, 133, $277-283$. http://dx.doi.org/10.1016/j.foodchem.2012.01.023

Naczk, M., Williams, J., Brennan, K., Liyanapathirana, C., \& Shahidi, F. (2004). Compositional characteristics of green crab (Carcinus maenas). Food Chemistry, 88, 429-434. http://dx.doi.org/10.1016/j.foodchem.2004.01.056

Padayatti, P. S. (1990). Notes on population characteristics and reproductive biology of the portunid crab Charybdis feriatus (Linnaeus) at Cochin. Indian Journal of Fisheries, 37, 155-158. Retrieved from http://epubs.icar.org.in/ojs-2.3.1-2/index.php/IJF/article/view/10459 
Ripps H., \& Shen, W. (2012). Review: taurine: a "very essential” amino acid. Molecular Vision, 18, 2673-2686. Retrieved from http://www.molvis.org/molvis/v18/a275

Risso, S. J., \& Carelli, A. A. (2012). Nutrient Composition of Raw and Cooked Meat of Male Southern King Crab (Lithodes santolla Molina, 1782). Journal of Aquatic Food Product Technology, 21, 433-444. http://dx.doi.org/10.1080/10498850.2011.608482

Rosa, R., \& Nunes, M. L. (2004). Nutritional quality of red shrimp, Aristeus antennatus (Risso), pink shrimp, Parapenaeus longirostris (Lucas), and Norway lobster, Nephrops norvegicus (Linnaeus). Journal of the Science of Food and Agriculture, 84, 89-94. http://dx.doi.org/10.1002/jsfa.1619

Skonberg, D. I., \& Perkins, B. L. (2002). Nutrient composition of green crab (Carcinus maenus) leg meat and claw meat. Food Chemistry, 77, 401-404. http://dx.doi.org/10.1016/S0308-8146(01)00364-8

Souchet, N., \& Laplante, S. (2007). Seasonal and geographical variations of sterol composition in snow crab hepatopancreas and pelagic fish viscera from Eastern Quebec. Comparative Biochemistry and Physiology Part B: Biochemistry and Molecular Biology, 147, 378-386. http://dx.doi.org/10.1016/j.cbpb.2007.02.001

Standards Press of China. (2003). Chinese Standard GB/T 5009.124-2003. Inspection of Grain and Oilseeds: Method for Determination of Amino Acids in Foods. Standards Press of China, Beijing, China.

Standards Press of China. (2008). Chinese Standard GB/T 22223-2008. Determination of total fat, saturated fat, and unsaturated fat in foods-hydrolytic extraction-gas chromatography. Standards Press of China, Beijing, China.

Tsape, K., Sinanoglou, V. J., \& Miniadis-Meimaroglou, S. (2010). Comparative analysis of the fatty acid and sterol profiles of widely consumed Mediterranean crustacean species. Food Chemistry, 122, 292-299. http://dx.doi.org/10.1016/j.foodchem.2010.02.019

Vinagre, A. S., Nunes do Amaral, A. P., Ribarcki, F. P., Fraga da Silveira, E., \& Périco, E. (2007). Seasonal variation of energy metabolism in ghost crab Ocypode quadrata at Siriú Beach (Brazil). Comparative Biochemistry and Physiology Part A: Molecular \& Integrative Physiology, 146, 514-519. http://dx.doi.org/10.1016/j.cbpa.2006.02.004

Wu, X., Zhou, B., Cheng, Y., Zeng, C., Wang, C., \& Feng, L. (2010). Comparison of gender differences in biochemical composition and nutritional value of various edible parts of the blue swimmer crab. Journal of Food Composition and Analysis, 23, 154-159. http://dx.doi.org/10.1016/j.jfca.2009.08.007

\section{Copyrights}

Copyright for this article is retained by the author(s), with first publication rights granted to the journal.

This is an open-access article distributed under the terms and conditions of the Creative Commons Attribution license (http://creativecommons.org/licenses/by/3.0/). 